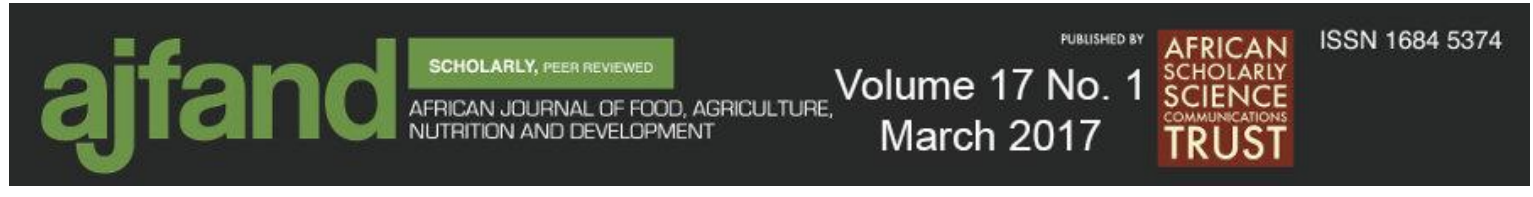

Afr. J. Food Agric. Nutr. Dev. 2017; 17(1): 11726-11742

DOI: 10.18697/ajfand.77.16065

\title{
COMPLEX AGRICULTURAL LIVELIHOODS AND AFLATOXIN EXPOSURE IN RURAL UGANDA
}

\author{
Agol $D^{1}$, Newton $\mathbf{R}^{2}$, Bukenya $\mathrm{D}^{3}$, Asiki $\mathbf{G}^{3}$, \\ Ssembajja $\mathrm{F}^{3}$, Tumwekwase $\mathrm{G}^{3}$ and $\mathrm{J}_{\text {Seeley }}{ }^{*}$
}

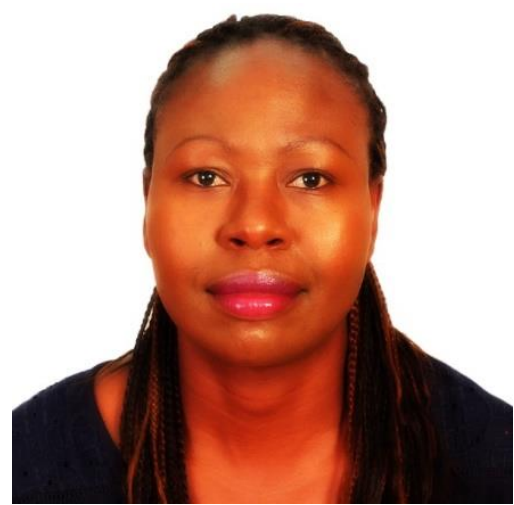

Dorice Agol

*Corresponding author email: Janet.seeley@1shtm.ac.uk

${ }^{1}$ School of International Development, University of East Anglia, UK

${ }^{2}$ Medical Research Council / Uganda Virus Research Institute (MRC/UVRI) Uganda Research Unit on AIDS, Entebbe, Uganda; Epidemiology and Cancer Statistics Group, Department of Health Sciences, University of York, UK; International Agency for Research on Cancer, Lyon, France

${ }^{3}$ Medical Research Council / Uganda Virus Research Institute (MRC/UVRI) Uganda Research Unit on AIDS, Entebbe, Uganda

${ }^{7}$ Medical Research Council / Uganda Virus Research Institute (MRC/UVRI) Uganda Research Unit on AIDS, Entebbe, Uganda; London School of Hygiene and Tropical Medicine, London, UK 


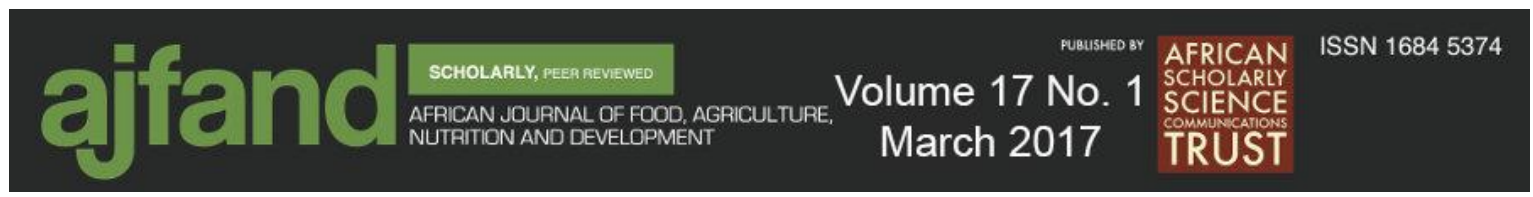

\begin{abstract}
Aflatoxins are secondary metabolites produced by Aspergillus flavus and A. parasiticus species of fungi. They are highly toxic and have been designated by the International Agency for Research on Cancer (IARC) as human carcinogens (Class 1: definitely carcinogenic to humans). High levels of exposure can cause acute hepatic necrosis and death while chronic exposure can cause carcinoma of the liver and possibly also growth impairment in children and compromised immunity. Contamination of crops most often occurs during harvest and storage, when damp, warm conditions allow the fungi to proliferate. Possible barriers to effective local interventions to reduce exposure were explored, by examining agricultural livelihoods and patterns of household food consumption within a population cohort in rural south west Uganda. Previous work in this cohort and elsewhere in Uganda showed that aflatoxin exposure was ubiquitous and that there are multiple sources of exposure. Data on agricultural practices were collected through a survey of 200 households; 22 of those were randomly selected for in-depth interviews. While crops such as maize, cassava, beans and groundnuts - all potential sources of aflatoxin - are grown, stored and consumed locally, the sale of home-grown foods, unfavourable climate, pests and diseases and limited labour, all facilitate food scarcities and subsequent insecurities leading to purchase of poorly stored foods which may also contain aflatoxins. Processed foods are easily accessible by many households, from the numerous trading centres established within villages. This paper gives background information on heterogeneity of household diets and seasonal trends in food consumption in rural Uganda and by so doing, identifies potential risk factors for aflatoxin contamination in the study area. Risks of aflatoxin contamination are multifaceted and this complexity makes it challenging to design and implement risk control measures and advocacy strategies. The argument of the paper is that the complexity of agricultural livelihoods and patterns of household food consumption in rural Uganda may mitigate the impact of simple, local interventions to reduce aflatoxin exposure. Therefore, intervention approaches need to take into account this complexity in order to minimize risk factors, especially amongst poor populations in rural areas.
\end{abstract}

Key words: Aflatoxin, agriculture, farming, consumption, food, intervention, rural areas, Uganda 


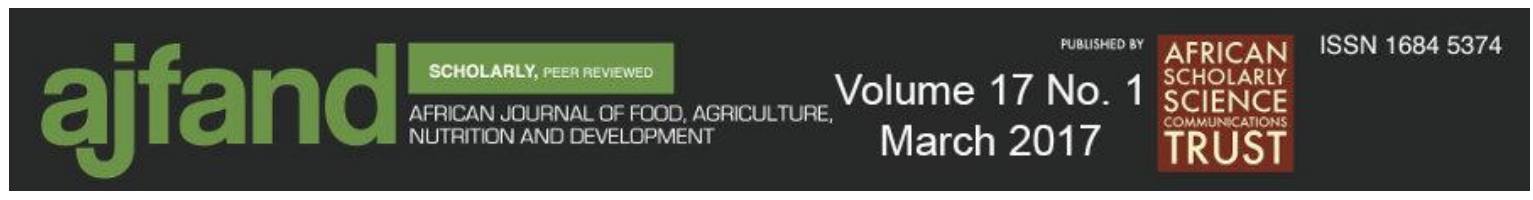

\section{INTRODUCTION}

Aflatoxins are secondary metabolites produced by species of fungi such as Aspergillus flavus and Aspergillus parasiticus. Contamination of crops most commonly occurs during harvest and storage, when damp warm conditions allow the fungi to proliferate [1]. Pre-harvest contamination of crops has also been reported mainly by Aspergillus flavus. They are highly toxic and have been designated by the International Agency for Research on Cancer (IARC) as human carcinogens (Class 1: carcinogenic to humans). High levels of exposure can cause acute hepatic necrosis and death while chronic exposure can cause carcinoma of the liver and possibly also growth impairment in children and compromised immunity $[2,3]$. Indeed, outbreaks of acute aflatoxicosis in Kenya in 2004 and 2005 resulted in more than 150 deaths; an expert panel was convened and highlighted four areas for immediate action: i) quantification of health impacts of aflatoxins, ii) intervention research, iii) surveillance and iv) emergency planning for outbreaks [4]. Since that time progress has been made in Kenya, including increasing investment and building new partnerships in research and technology to facilitate aflatoxin control measures.

Aflatoxins can be measured directly in foodstuffs, and human exposure can be assessed at the individual level by measuring aflatoxin-albumin (AF-alb) adducts in blood and in urine. Foods for consumption by humans and animal feed are routinely monitored and strictly regulated for aflatoxin contamination as part of standard food safety practices in most developed countries. In many low and middle income countries, regulations, even if present, are less frequently enforced and food shortages can exacerbate exposure to heavily contaminated products. Despite aflatoxin having a known detrimental effect on human health, information on human exposure and prevention measures are more limited in resource constrained settings, especially in rural areas.

The level of risk of aflatoxin contamination is determined, in large part, by the quality of food drying, storage facilities and services at home and in the market place [5-10]. Foods stored in damp conditions and/or for prolonged periods of time (usually more than three months) can have increased levels of aflatoxin. In agro-ecological zones where weather conditions are moist, the risk is higher compared to cool dry areas $[8,10]$. This is because moist conditions tend to encourage mould formation.

Until recently there was no systematic study that examined levels of aflatoxin in people in rural Uganda. Working within an established rural population cohort in southern central Uganda, Asiki and colleagues [1] and Kang and colleagues [11] demonstrated that exposure to aflatoxins was ubiquitous and that a significant proportion of people tested had relatively high levels, similar to those found in other settings in Africa. Furthermore, levels of aflatoxin had not changed significantly over the two decades for which data were available. This suggests that there is a need for intervention studies in this setting aimed at reducing levels of contamination of foodstuffs.

Potentially, there are a number of ways to reduce human consumption of aflatoxin, both pre- and post-harvest (primary prevention). Aspergillus spp. infects crops as they grow and aflatoxin accumulates after crop harvest when storage conditions are inadequate. 


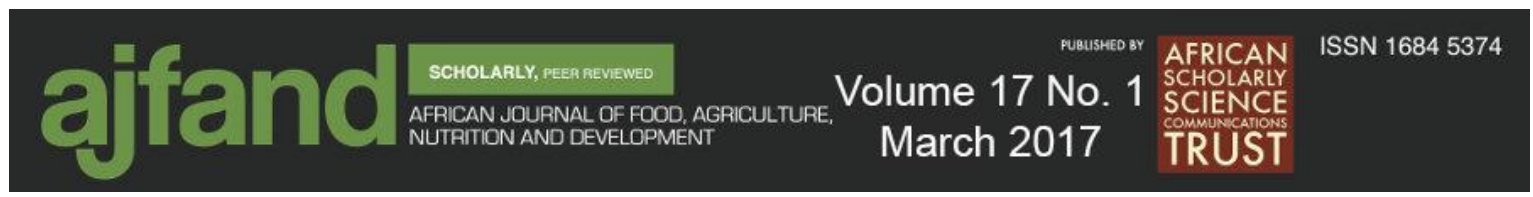

Instigating practical and sustainable interventions that focus on the timing of harvest, crop drying and storage, processing and cooking may reduce aflatoxin levels [3]. In 2005, Turner and colleagues published the results of an intervention to reduce human aflatoxin exposure by introducing simple, low-technology post-harvest measures to reduce contamination of groundnuts [12]. Using a randomized community-based intervention trial in Guinea [12], the researchers demonstrated substantial reductions in aflatoxin exposure (as measured in serum), but the reproducibility and sustainability of the findings has yet to be established in different settings. The authors had previously demonstrated that the main route of exposure to aflatoxin was in groundnuts [13]; in other settings, however, there may be multiple sources of exposure.

Since many rural livelihoods in sub-Saharan African countries depend, to a greater or lesser extent, on subsistence production of crops such as maize [14, 15], it is important to understand the specific sources of aflatoxin exposure across diverse environments, in order to target adequately potential interventions. In Uganda, contamination by aflatoxin of many staple foods, including maize, cassava, groundnuts and locally manufactured baby foods (including baby soya and rice porridge) has been reported [8, 16-19]. Similarly, elsewhere in Africa, Atehnkeng and colleagues [20] reported contamination of maize in three agro-ecological zones in Nigeria. In western Kenya, Mutegi and colleagues [9] showed that the most aflatoxin-contaminated foods were groundnut-based and that this compromised food quality for many households. In Cameroon, the risk of contamination by aflatoxin was found in cassava [6]. Brewing alcohol can also be risky because it offers favourable conditions for the growth of fungus which produce aflatoxins. Millet, sorghum and maize are commonly used for alcohol production and the brews are a result of mixed-culture fermentation, a process which continues up to the point of consumption [21].

This highlights that any interventions to reduce aflatoxin exposure need to be both evidence-based and context-specific within a particular community setting, or within the wider population. For example, the relative proportion of different foodstuffs within a diet that is grown locally for personal consumption, or imported and purchased from elsewhere, may vary across communities. Furthermore, locally produced foodstuffs, such as maize, may be milled in local mills in combination with produce from other farmers, which could result in contamination of the final milled product.

With a view to planning an intervention to reduce aflatoxin exposure in a rural Ugandan community, an analysis of both quantitative and qualitative data was conducted from a study examining cropping patterns, sale, purchase and consumption of foodstuffs, conducted within the same population as that studied by Asiki and colleagues [1] and Kang and colleagues [11].

The purpose of this paper is to provide an overview of the farming context in which aflatoxin contamination and the consumption of products affected by aflatoxin may occur, in order to highlight some of the challenges that interventions designed to address aflatoxin exposure may face in such settings. 


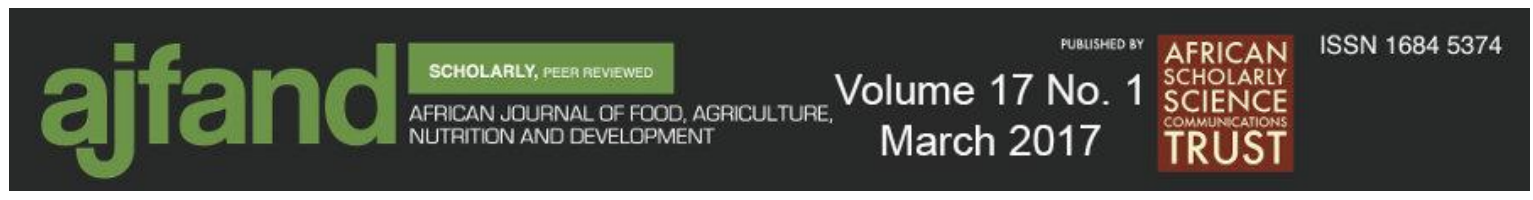

\section{MATERIALS AND METHODS}

This study of agricultural practice and household consumption of foodstuffs was conducted within the context of an existing population-based cohort study, the General Population Cohort (GPC) [22]. This cohort was originally established in 1989, by the UK Medical Research Council (MRC) and the Uganda Virus Research Institute (UVRI), in Kalungu District, southern-central Uganda, to examine prevalence, incidence, risk factors and trends of infection with the human immunodeficiency virus (HIV) in a rural African population [22, 23]. More recently, research activity has broadened to include the epidemiology and genetics of other communicable and of non-communicable diseases (NCDs), including cancer, cardio-vascular disease and diabetes [24].

In brief, the GPC is a community-based open cohort study of residents of neighbouring villages within a sub-county, lying about $40 \mathrm{~km}$ from the shores of Lake Victoria. The population is scattered across the county-side in villages defined by administrative boundaries with a few concentrated in small trading centres [22]. A population of approximately 10,000 people in a cluster of 15 villages was studied from 1989 to 1999 . In 2000 the GPC was expanded to cover a further 10 villages [1]. The cohort is dynamic with new births, deaths and migration reported at each round of follow-up and the population under survey includes approximately 22,000 people [1]. Data are collected through an annual census, questionnaire and serological survey [1]. Agriculture is the main livelihood activity and is mainly rain-fed [1].

Data on agricultural practices from 1990-2009 within the GPC area were collected in 2009 from 200 randomly selected households, using questionnaires, as part of a study funded by the Food and Agriculture Organization (FAO), which focused on the impact of the HIV epidemic on agriculture-based livelihoods [24]. Data from the 200 households included age, sex, number of household members, land size, types of crops, livestock and poultry, as well as type and number of labourers used. This allowed examination of the proportion of households growing staple crops and of household consumption of foodstuffs [1]. In addition, qualitative data were gathered for a calendar year (2009-10), using in-depth interviews with the members of 22 households (household heads and nonhousehold heads) who were randomly selected from the sample of 200 households and spread throughout the 25 study villages. In addition to details of monthly agricultural activities, food consumption patterns were also investigated for the 22 households. In a separate investigation, three shops and a market in the largest trading centre in the study area were visited and the vendors questioned about the source of the products they sold.

Quantitative data were analysed using Microsoft Excel and Statistical Package for Social Science (SPSS) software. Basic descriptive statistics were conducted on sociodemographic and economic status of the households. Trends in annual crops, cropping patterns, land size, labour and household diets were examined. The qualitative data were analysed using both data led and theory led content analysis. A list of themes was developed and agreed by members of the research team before manual coding was undertaken, by four team members, who discussed their approach to coding as they went along to ensure consistency. 


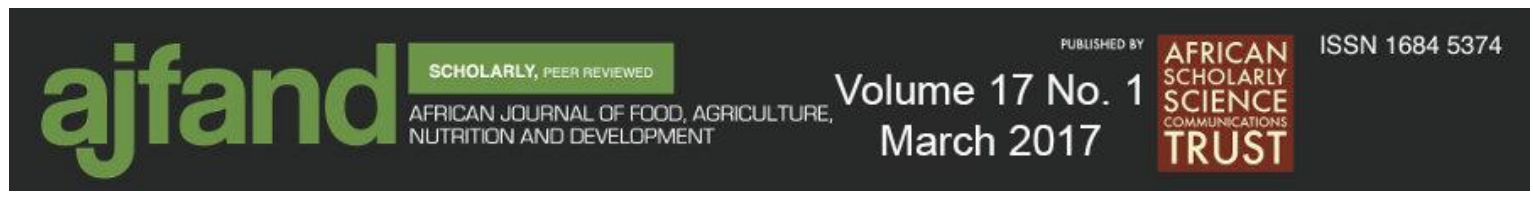

Ethical approval for the collection of data included in this paper was granted by the Science and Ethics Committee of the Uganda Virus Research Institute and overall clearance by the Uganda National Council for Science and Technology. All study participants provided written informed consent.

\section{RESULTS}

Of the 200 households, $60 \%$ were male headed and $40 \%$ female headed; mean age of respondents was 40 years. On average each household comprised of seven members connected by blood (primarily first degree relatives). From the household members who participated in the qualitative study, fewer than half attained post-primary education, primarily due to poverty, early marriage and teenage pregnancy. The main livelihood activities include crop cultivation, livestock and poultry keeping and small businesses (for example, the sale of food and handicrafts, such as mats and baskets) and service industries such as farm labouring and motorbike transport. The major crops grown include beans, coffee, Matooke (cooking bananas), maize, groundnuts, sweet potatoes and cassava (Figure 1). Many of these crops are grown for both home consumption and cash generation. 

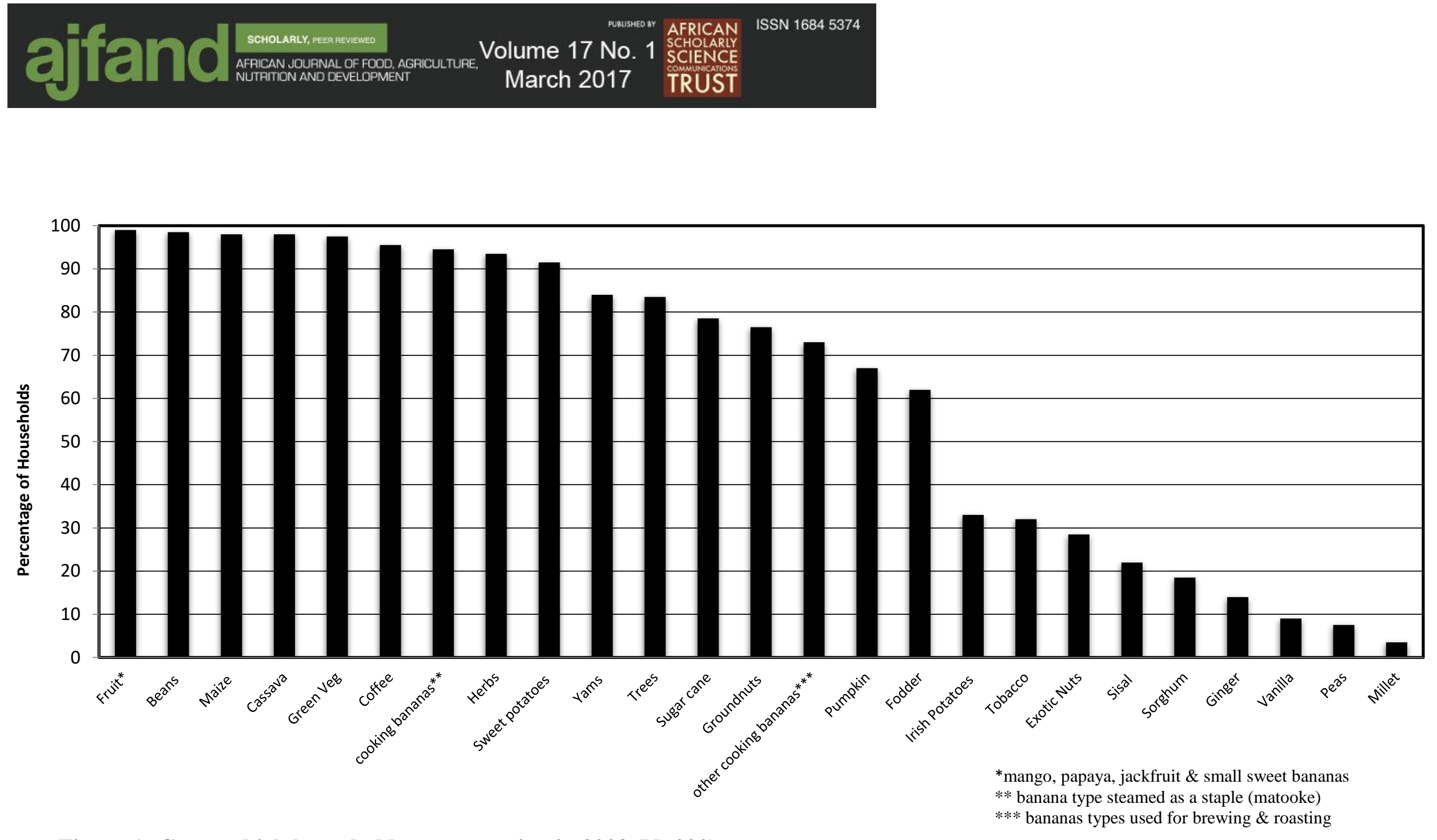

Figure 1: Crops which households were growing in $2009(\mathrm{~N}=\mathbf{2 0 0})$ 


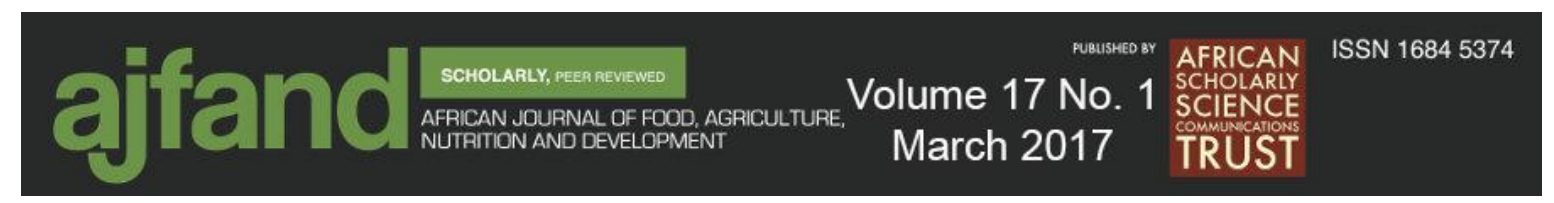

\section{Patterns of cropping}

By 2009, households' members were growing a variety of crops, but mainly Matooke (cooking bananas), coffee, beans, maize, sweet potatoes, cassava and groundnuts. Other crops such as Irish potatoes, sweet bananas, papaya, passion/jack fruit, mangoes, green vegetables and other varieties of bananas were also grown. However, crop mixes changed from time to time. Results from the in-depth interviews with 22 households showed that several factors influenced changes in the cropping patterns. These included food insecurity, the need to generate income, inclement weather, pest/disease vulnerability, price volatility, poor human health, decreases in land size, limited farm labour and capital.

Crop yields have been unpredictable from year to year in the area and were reported as being very low throughout 2009, relative to other years, as well as towards the end of 2010 and, as a result, many households were facing food shortages. Prolonged drought, pests and diseases were the principal causes of crop losses notably for coffee, beans, maize and sweet potatoes during that year (2009). Since agriculture is mainly rain-fed, any changes in weather conditions have had significant influence in cropping patterns in the area. Throughout 2009 and towards the end of 2010, the rains failed and many crops such as coffee, maize and beans failed. During this time, cassava, which is grown throughout the year and is relatively hardy, is a valued source of sustenance. Food, including maize flour, was also purchased from local trading centres and other farmers to make up the deficit that many households faced.

Due to unpredictable food prices especially during periods of scarcities, the need to diversify crop production was desirable. With adequate rain falling at the beginning of 2010, people became optimistic about the prospects of good yields so more effort was put into growing additional crop varieties of bananas, beans, maize, sweet potatoes and cassava. For example, some individuals started to grow new and improved varieties of bananas and beans; others expanded the area under cultivation. As yields were good in early 2010, these crops were sold to generate cash, in order to meet needs such as clothing, medical care and education; this was the practice during good harvest times. Some households were able to use the extra cash generated from crop sales to buy/rent more land and/or hire farm labour while others engaged in additional activities such as keeping livestock and poultry and operating small businesses. However, cash was also needed during poor harvest times for food purchase as well as other items. It was not uncommon to sell household produce to generate cash in periods of poor harvests. This can also occur when household members are faced with difficult situations such as sicknesses and death and are in need of cash to cover the incurred expenses. The obvious consequence of selling off their own produce is that some households have experienced food shortages long before the next harvesting season. This has meant buying food (processed and unprocessed) elsewhere to meet household food demands.

Availability of land has also influenced patterns of food production and subsequent food security in the area. Although land acquisition is mainly through inheritance, buying, renting, lending and borrowing are also common practices for many households. The quantitative analysis of data from 200 households showed that land size per household decreased from 4.9 acres in 1990 to 3.2 acres in 2009. Over this period, perhaps because of the decreasing land size and/or because of advice on agricultural practice, people increasingly practised intercropping and it became common to grow maize, beans, cassava, bananas and sweet potatoes in different combinations. In other cases, bananas, which had been grown on the same 


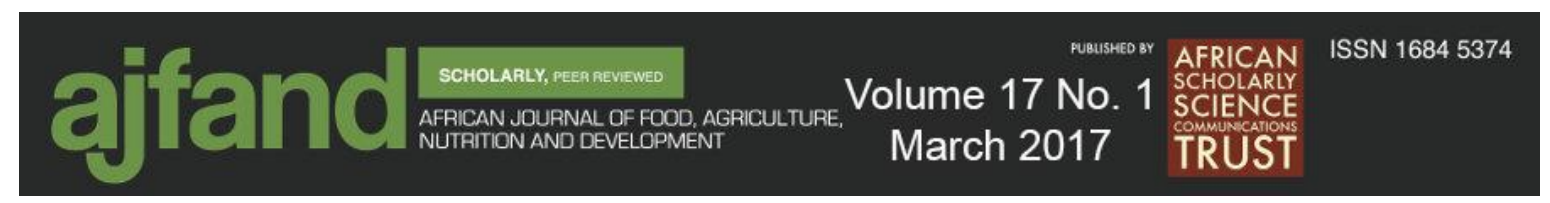

piece of land over a long period of time, were replaced with other crops because of reduced productivity, due either to declining soil fertility or pests and diseases [24].

Other factors such as the availability of labour and the health status of household members have also influenced farming efforts. Key activities requiring labour include preparing fields, planting, weeding, harvesting, transporting and processing (for example, removing maize off the cobs). In the analysis of quantitative data, it was found that the majority of households used free labour mainly from family and friends. However, some households faced a labour shortage when a family member fell ill. Where paid labour was used, the average number of people hired was two. Paid labour was considered expensive especially during land preparation such as tilling and weeding. Beans, bananas, maize and coffee were considered labour intensive and only households which could afford labourers, or had family labour available, were able to grow such crops in significant quantities.

\section{Household diet and food consumption patterns}

In 2009/2010, household members' diet comprised mainly of Matooke, maize meal, beans, cassava, sweet potatoes, pumpkins, yams, groundnut, meat, fish, fruit and vegetables.

Historically, green Matooke (which is eaten cooked) is the staple food and is the preferred source of daily energy intake for the majority of households. Most households prepare sauces made out of beans, groundnuts, meat or fish and which are eaten with Matooke and/or, increasingly, with maize meal/flour.

Household members fulfilled their food consumption needs through a combination of farm production, market purchases and donations from family and friends. Of the 22 households investigated in more detail, all respondents reported purchasing processed maize meal and other foods such as rice, Matooke, fruit or vegetables from the local markets. Over the last two decades accessing these foods has become easier as several trading centres have emerged. Currently, there are over ten trading centres in the study area and several shops operate in these centres and sell a variety of processed and unprocessed foods produced both locally and from outside the area. Processed and ready-made meals of Matooke, maize flour, groundnuts and beans are common in these trading centres' eating places and markets. When questioned, local vendors indicated that the beans, Matooke and some fresh fruits and vegetables that they sold, were purchased from local farmers, but that the maize flour (posho), pounded groundnuts, rice and millet, were purchased from retailers in more distant large towns (Masaka, Mbarara and Kampala) - the original source of the foodstuffs is unclear and the products could even be from outside of Uganda.

As noted above, in 2009 crop failures were widespread mainly due to prolonged drought and subsequently all the 22 households reported experiencing food shortages which extended into the beginning of 2010. All the 22 households reported buying food during the first months of 2010 as well as receiving food donations from friends and relatives. The harvesting season began at the beginning of April 2010 and a quarter of the 200 households reported starting to consume fresh vegetables, sweet potatoes and cassava harvested from their own farms, while the rest continued to buy foods, mainly processed maize and rice from the local shops. Table 1 shows monthly food consumption patterns throughout 2010 within the 22 households.

Consumption of processed maize meal was found to be common, especially at the beginning of 2010 when home-grown food was scarce. From May 2010, most households were harvesting 


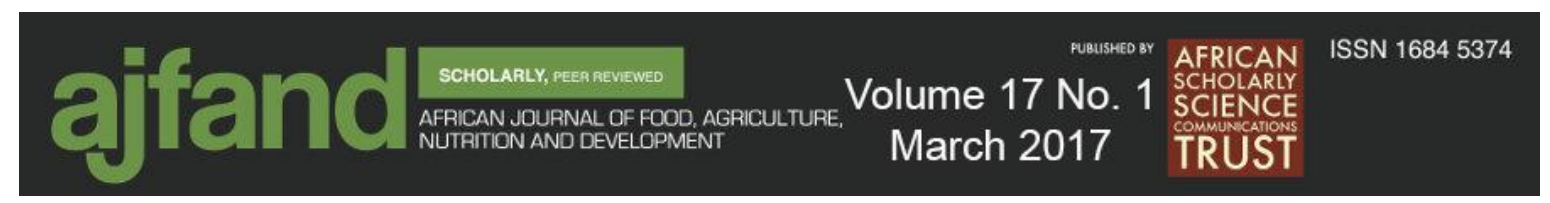

a variety of crops including bananas, beans, sweet potatoes, cassava, pumpkins and vegetables. Yields for these crops were good and three quarters of the households reported eating a diverse diet (more than four different types of staple food) until July. Freshly harvested foods such as Matooke, green maize, fresh beans and vegetables were popular in household diets. Extra foods, particularly beans and maize kernels, not consumed by the family, were dried and stored for later consumption, sale or planting.

In August 2010, household members' diets were less diverse because the harvesting period was over and access to fresh foods derived from their own farms became limited. Land clearance and preparation for planting in the new season was a common activity. More than half of the participants reported eating Matooke, dried beans and maize meal, but not all were harvested from their own farms. Most people bought processed maize meal from the markets and some ate rice which was bought from local shops. In September and October, people were still eating Matooke, sweet potatoes, cassava, dried beans and maize meal. Most indicated that they were still obtaining Matooke from their own farms, others purchased from the local markets. Some individuals sold a part of their food harvests to raise money for the purchase of other foods, clothing, house construction, medical and school fees. Beans were commonly sold, although coffee is the most popular crop for generating income in the area. Food sales subsequently led to shortages as some households ran out of food before the following harvesting season.

Crop failures in late 2010 (second season) were a major concern as expressed in the examples below:

“.....I don't think I will get even a tumpeco [meaning a plastic cup] of dried beans from my garden. Ever since you left we have experienced much sunshine and the crops are affected. They had flowered but all the flowers fell down and now if you happen to see my beans, the leaves have a yellow colour as if they are ready for eating." (Household No. 3, October 2010).

"We completed planting beans and maize and unfortunately my crops are being affected by sunshine. By this time my beans would be flowering instead the leaves have turned yellow. The leaves of maize are also yellow and I think my cassava which I planted has dried up, I don't see it yielding. This time I am worried it seems we are going to face a food shortage." (Household No 1, October 2010).

During dry weather conditions when food is scarce, many households opted to purchase foods, both locally, or from further afield. Notably, buying Matooke, beans and maize meal became common. Some individuals exchanged food for labour mainly by working on other people's farms. When asked whether their households were food secure, nearly all the respondents said "No". Prices of major crops such as Matooke increased leading some households to go for relatively cheaper and more affordable foods such as cassava and wild green vegetables (found in the areas around their cultivated land), for example:

"I had left some few dry beans and now they are over, groundnuts are over; we have been taking silver fish [a small dried fish - Rastreneobola argentea] and dodo [a type of spinach]. By this time I would be eating fresh beans but the beans are affected." (Household No. 7, November 2010).

Besides bad weather, other factors that caused food shortages and subsequent changes in household diets were general poverty and lack of cash to buy food, unproductive land for 


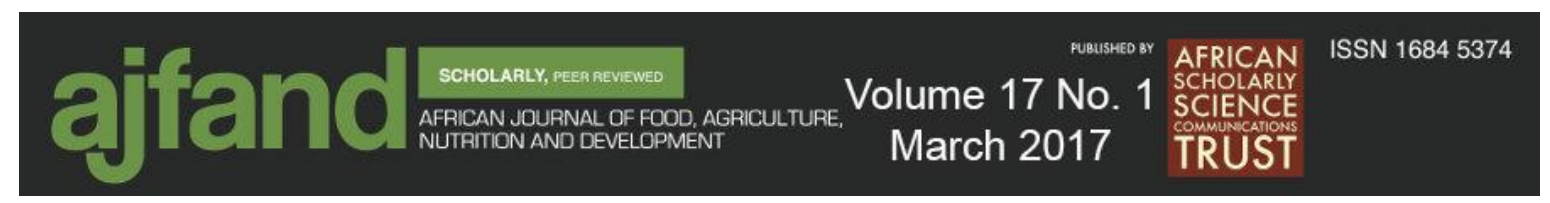

farming and lack of farm labour. Some households indicated that the land they cultivated was unproductive and that they lacked money to buy farm inputs such as fertilizers, in the hope that they would improve the chance of a good harvest.

\section{DISCUSSION}

The findings on agricultural production and food consumption patterns highlight the complex background to the nature of risks of exposure to aflatoxin in poor rural settings where determinants of exposure and contamination are intricately linked to livelihood dynamics and influenced by factors such as food security and land tenure. There is evidence from research that many households in the study area in rural Uganda are increasingly growing cereals, legumes and tubers such as maize, beans, cassava, sweet potatoes and groundnuts [25]. Examples from other settings have shown that crops such as maize and groundnuts are prone to severe infestations by aflatoxin-producing fungi, leading to contamination and compromising food quality $[6,8,20,26-34]$.

Many rural economies are changing from subsistence to increased cash cropping and as this study has shown, it is common practice to sell crops such as maize, beans and Matooke to generate income to improve livelihoods. However, this behaviour can reduce food availability per capita consumption if individuals sell food which was produced and meant for members of the household. Buying food is a common coping strategy during scarcities and as one moves farther along the supply chain from the source of food production, the likelihood of purchasing foods which may have been contaminated with aflatoxin increases, due to inadequate storage and improper handling. Mutegi and colleagues [9], for example, found that many of the storage facilities in market outlets in Western Kenya were dusty and poorly ventilated and that groundnuts were packed in plastic materials which were likely to encourage aflatoxin contamination.

Aflatoxin contamination is common in processed foods such as ground maize (maize meal), peanut butter or sauce, cassava as well as dried vegetables and spices [8, 30, 32, 34, 35, 37]. Households around the numerous trading centres in the study area are at risk of aflatoxin exposure because they can now more easily access processed foods such as maize, millet, sorghum, cassava and groundnut flour. Asiki and colleagues [1] found that individuals who lived closest to trading centres were at higher risks of exposure to aflatoxin, including babies who were weaned on processed millet, sorghum and soya, which were not grown locally.

In a previous randomised trial, Turner and colleagues [12] demonstrated a 50\% reduction in aflatoxin levels within people in the intervention arm of the study. It was conducted in 20 villages in rural Guinea in which subsistence farms in ten were subjected to a low-technology approach to reduce post-harvest contamination of ground nuts with aflatoxin. The intervention included education on hand sorting of groundnuts, drying procedures, provision of natural fibre bags and pallets for storage and use of insecticide. However, this study highlights that the factors that determine risk of aflatoxin exposure in rural Uganda are more complex and multifaceted in nature than in the setting of the Guinea study. For example, the problems associated with designing an intervention to improve storage conditions for multiple crop types (rather than just ground nuts), thereby reducing aflatoxin exposure, are manifest. Indeed, the ability to assess the success or failure of such an intervention in rural populations may be compromised by the complexities of food supply with people consuming their own crops as 


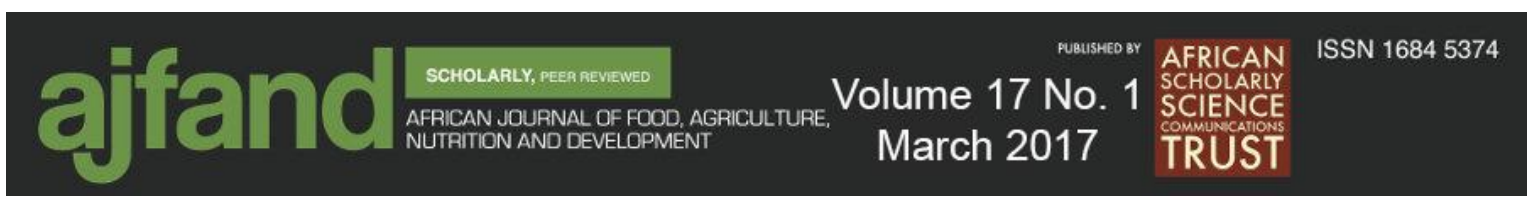

well as external sources of food. Reductions in aflatoxin levels within locally produced food may not correlate with reductions in levels detected in people. As the findings presented in this paper show, people do not rely just on the food they grow, but also purchase food from external sources or are given supplies by neighbours and relatives when they are short. Conversely, they sell food for export to other areas. If the primary source of aflatoxin in a community is from those stored food products imported into the area, then the impact of local interventions may be limited. Indeed, the complexity of agricultural livelihoods and patterns of household food consumption in rural Uganda may mitigate the impact of simple, local interventions to reduce aflatoxin exposure. Perhaps, therefore, widespread efforts to reduce aflatoxin contamination of foodstuffs (using simple post-harvest measures highlighted above) will need to be made.

\section{CONCLUSION}

In conclusion, attention is drawn to the complexity of providing evidence-based policy recommendations especially in settings where it may be difficult to enforce food quality related measures to reduce aflatoxin exposure due to recurring food scarcities and varied sources of foodstuffs.

\section{ACKNOWLEDGEMENTS}

Funding for this study was provided by Swedish International Development Cooperation Agency (SIDA), through FAO, the Economic and Social Research Council (Res 189-25-0013) the Medical Research Council and Department for International Development (all of the UK Government). We are grateful for the Social Science programme team for data collection and to all the participants, including all the members of the households who participated for the time they gave to our research.

\section{AUTHOR CONTRIBUTIONS}

Robert Newton and Janet Seeley developed the idea for the paper. Dorice Agol undertook data analysis in consultation with Dominic Bukenya, Fatuma Ssembajja and Grace Tumwekwase and drafted the first version of the paper. Robert Newton, Janet Seeley, Gershim Asiki and Dorice Agol refined the drafts of the paper. All authors commented on the final version of the paper and approved the contents.

\section{CONFLICTS OF INTEREST}

The authors declare that they have no competing interests. 


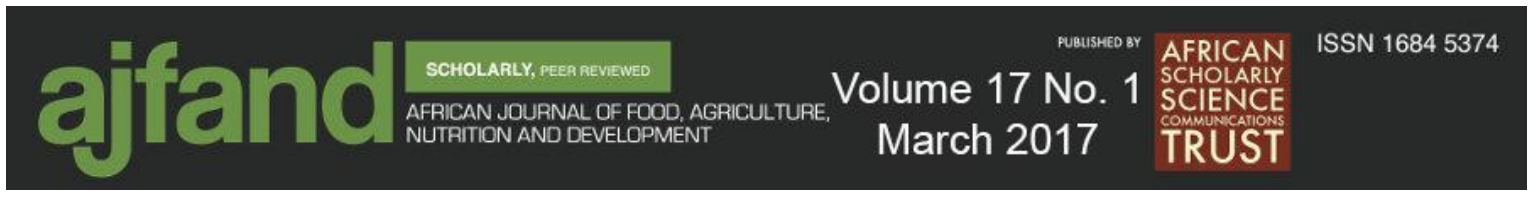

Table 1: Ranking food consumption for 22 households in 2010 (5 stars denote in plenty and popular in the diet; 1 star means scarce; 0 means not in diet at all)

\begin{tabular}{|c|c|c|c|c|c|c|c|c|c|c|c|c|}
\hline & Jan & Feb & Mar & Apr & May & Jun & July & Aug & Sept & Oct & Nov & Dec \\
\hline Matooke & $* *$ & $* *$ & $* * *$ & $* * *$ & $\begin{array}{c}* * * * \\
*\end{array}$ & $* * * * *$ & $\begin{array}{c}* * * * \\
*\end{array}$ & $* * * *$ & $* * * *$ & $* *$ & $* *$ & $* *$ \\
\hline Fresh beans & 0 & 0 & $* *$ & $* * *$ & $\begin{array}{c}* * * * \\
*\end{array}$ & $* * * * *$ & $* * * *$ & $* *$ & 0 & 0 & $* *$ & $* *$ \\
\hline Dried Beans & $* *$ & $* *$ & $* *$ & $* * *$ & $* *$ & $* *$ & $* *$ & $* *$ & $* * *$ & $* *$ & $* * *$ & $* * *$ \\
\hline Green Maize & 0 & 0 & 0 & $*$ & $* * * *$ & $\begin{array}{c}* * * * * \\
*\end{array}$ & $* * * *$ & $* * *$ & 0 & 0 & $* * *$ & $* * *$ \\
\hline Maize meal & $* * * * *$ & $* * * * *$ & $* * * * *$ & $* * * *$ & $* * *$ & $* * *$ & $* * *$ & $* * *$ & $* * * *$ & $* * * *$ & $* * * *$ & $* * * *$ \\
\hline Cassava & $* *$ & $* * *$ & $* * * *$ & $\begin{array}{c}* * * * \\
*\end{array}$ & $\begin{array}{c}* * * * \\
*\end{array}$ & $* * * * *$ & $\begin{array}{c}* * * * \\
*\end{array}$ & $* * * *$ & $* * * *$ & $* * *$ & $* * *$ & $* * *$ \\
\hline Sweet potatoes & $*$ & $* * *$ & $* * *$ & $\begin{array}{c}* * * * \\
*\end{array}$ & $\begin{array}{c}* * * * \\
*\end{array}$ & $* * * * *$ & $* * * *$ & $* * *$ & $* * * *$ & $* * *$ & $* * *$ & $* * * *$ \\
\hline Groundnut sauce & $* * *$ & $* * *$ & $* * * *$ & $* * * *$ & $* * *$ & $* * * *$ & $* * * *$ & $* * * *$ & $* * *$ & $* * *$ & $* * * *$ & $* * * *$ \\
\hline Rice & $* *$ & $* * *$ & $* * *$ & $* * *$ & $* * *$ & $* * *$ & $* * *$ & $\begin{array}{c}* * * * \\
*\end{array}$ & $* * *$ & $* * *$ & $* * *$ & $* * *$ \\
\hline Vegetables & $*$ & $* * *$ & $* * *$ & $* * *$ & $\begin{array}{c}* * * * \\
*\end{array}$ & $* * * * *$ & $\begin{array}{c}* * * * \\
*\end{array}$ & $\begin{array}{c}* * * * \\
*\end{array}$ & $\begin{array}{c}* * * * \\
*\end{array}$ & $* *$ & $* * *$ & $* * *$ \\
\hline Pumpkins & 0 & 0 & $* * * *$ & $* * * *$ & $\begin{array}{c}* * * \\
*\end{array}$ & $* * * *$ & $* * * *$ & $* * * *$ & $* * * *$ & $* *$ & $* *$ & $* *$ \\
\hline
\end{tabular}




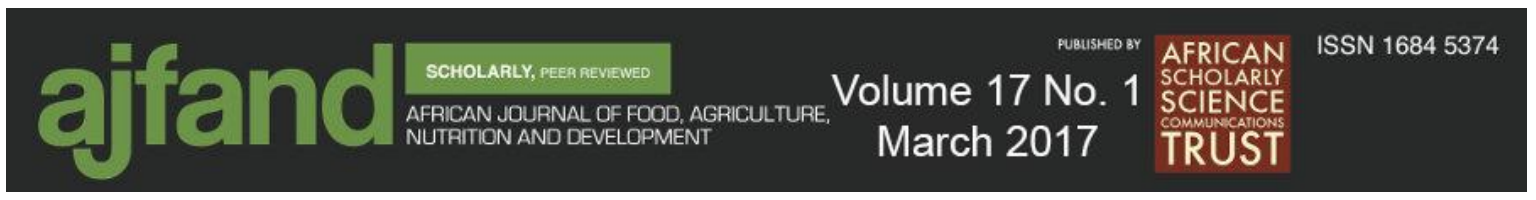

\section{REFERENCES}

1. Asiki G, Seeley J, Srey C, Baisley K, Lightfoot T, Archileo K, Agol D, Abaasa A, Wakeham K, Routledge MN, Wild CP, Newton R and YY Gong A pilot study to evaluate aflatoxin exposure in a rural Ugandan population. Tropical Medicine \& International Health. 2014;19(5):592-9. doi:10.1111/tmi.12283.

2. IARC. IARC Monographs on the evaluation of carcinogenic risks to humans; some traditional herbal medicines, some mycotoxins, naphthalene and styrene. Lyon , France: IARC Press; 2002.

3. Wild CP and YY Gong Mycotoxins and human disease: a largely ignored global health issue. Carcinogenesis. 2010;31(1):71-82.

4. Strosnider H, Azziz-Baumgartner E, Banziger M, Bhat RV, Breiman R, Brune MN, DeCock K, Dilley A, Groopman J, Hell K, Henry SH, Jeffers D, Jolly C, Jolly P, Kibata GN, Lewis L, Liu X, Luber G, McCoy L, Mensah P, Miraglia M, Misore A, Njapau H, Ong CN, Onsongo MT, Page SW, Park D, Patel M, Phillips T, Pineiro M, Pronczuk J, Rogers HS, Rubin C, Sabino M, Schaafsma A, Shephard G, Stroka J, Wild C, Williams JT and D Wilson Workgroup report: public health strategies for reducing aflatoxin exposure in developing countries. Environmental Health Perspectives. 2006;114(12):1898-903.

5. Atukwase A, Kaaya AN and C Muyanja Dynamics of Fusarium and fumonisins in maize during storage - A case of the traditional storage structures commonly used in Uganda. Food Control. 2012;26(1):200-5. doi:

http://dx.doi.org/10.1016/j.foodcont.2012.01.016.

6. Essono G, Ayodele M, Akoa A, Foko J, Filtenborg O and S Olembo Aflatoxinproducing Aspergillus spp. and aflatoxin levels in stored cassava chips as affected by processing practices. Food Control. 2009;20 (7):648-54. doi:

http://dx.doi.org/10.1016/j.foodcont.2008.09.018.

7. Hell K, Cardwell KF, Setamou M and HM Poehling The influence of storage practices on aflatoxin contamination in maize in four agroecological zones of Benin, west Africa. Journal of Stored Products Research. 2000;36(4):365-82. doi: http://dx.doi.org/10.1016/S0022-474X(99)00056-9.

8. Kaaya AN and W Kyamuhangire The effect of storage time and agroecological zone on mould incidence and aflatoxin contamination of maize from traders in Uganda. International Journal of Food Microbiology. 2006;110(3):217-23. doi: http://dx.doi.org/10.1016/j.ijfoodmicro.2006.04.004.

9. Mutegi C, Wagacha M, Kimani J, Otieno G,Wanyama $\mathbf{R}$ and $\mathbf{K}$ Hell Incidence of aflatoxin in peanuts (Arachis hypogaea Linnaeus) from markets in Western, Nyanza and Nairobi Provinces of Kenya and related market traits. Journal of Stored Products Research. 2013;52(0):118-27. doi: http://dx.doi.org/10.1016/j.jspr.2012.10.002. 


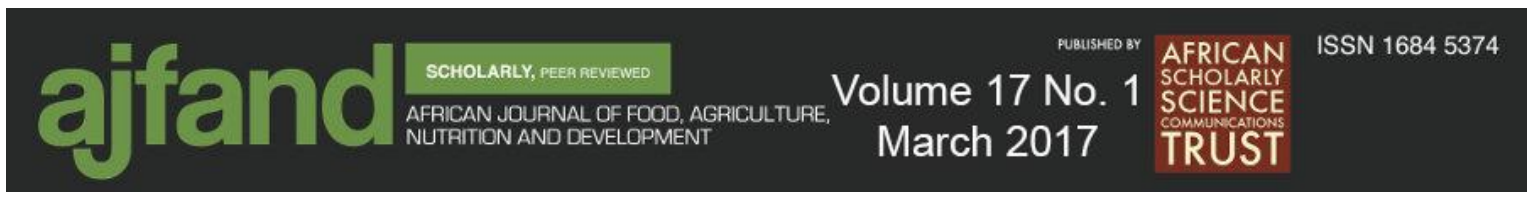

10. Udoh JM, Cardwell KF and T Ikotun Storage structures and aflatoxin content of maize in five agroecological zones of Nigeria. Journal of Stored Products Research. 2000;36(2):187-201. doi: http://dx.doi.org/10.1016/S0022-474X(99)00042-9.

11. Kang MS, Nkurunziza P, Muwanika R, Qian G, Tang L, Song X, Xue K, NkwataA, Ssempebwa J, Lutalo T, Asiki G, Serwadda D, Seeley DJ, Kaleebu P, Nalugoda F, Newton R, Williams JW and JS Wang Longitudinal evaluation of aflatoxin exposure in two cohorts in south-western Uganda. Food Additives and Contaminants: Part A. 2015(ahead-of-print):1-9.

12. Turner PC, Sylla A, Gong YY, Diallon MS, Sutcliffe MSAE and AJ Hall Reduction in exposure to carcinogenic aflatoxins by postharvest intervention measures in west Africa: a community-based intervention study. The Lancet. 2005;365(9475):1950-6. doi:10.1016/s0140-6736(05)66661-5.

13. Diallo MS, Sylla A, Sidibé K, Sylla BS, Trepo CR and CP Wild Prevalence of exposure to aflatoxin and hepatitis B and C viruses in Guinea, West Africa. Natural Toxins. 1995;3(1):6-9.

14. Kudadjie CY, Struik PC, Richards P and SK Offei Assessing production constraints, management and use of sorghum diversity in north-east Ghana: a diagnostic study. NJAS - Wageningen Journal of Life Sciences. 2004;52(3-4):371-91. doi: http://dx.doi.org/10.1016/S1573-5214(04)80022-8.

15. Tittonell P, Muriuki A, Shepherd KD, Mugendi D, Kaizzi KC and J Okeyo The diversity of rural livelihoods and their influence on soil fertility in agricultural systems of East Africa - A typology of smallholder farms. Agricultural Systems. 2010;103(2):83-97. doi: http://dx.doi.org/10.1016/j.agsy.2009.10.001.

16. Kaaya A and $\mathbf{H}$ Warren Aflatoxin in baby foods in Uganda. African Journal of Food, Agriculture, Nutrition and Development. 2005;5(1):1-19.

17. Kaaya A, Warren H, Adipala E, Kyamanywa S, Agona J and G Bigirwa Mould incidence and mycotoxin contamination of maize and groundnuts in Mayuge and Kumi districts of Uganda. African Crop Science Conference Proceedings; 2001.

18. Kaaya A, Harris $\mathbf{C}$ and $\mathbf{W}$ Eigel Peanut aflatoxin levels on farms and in markets of Uganda. Peanut Science. 2006;33(1):68-75.

19. Kaaya A, Kyamuhangire $\mathbf{W}$ and $\mathbf{S}$ Kyamanywa Factors affecting aflatoxin contamination of harvested maize in the three agroecological zones of Uganda. Journal of Applied Sciences. 2006;6:2401-7.

20. Atehnkeng J, Ojiambo PS, Donner M, Ikotun T, Sikora RA and PJ Cotty Distribution and toxigenicity of Aspergillus species isolated from maize kernels from three agro-ecological zones in Nigeria. International Journal of Food Microbiology. 2008;122(1-2):74-84. doi: http://dx.doi.org/10.1016/j.ijfoodmicro.2007.11.062. 


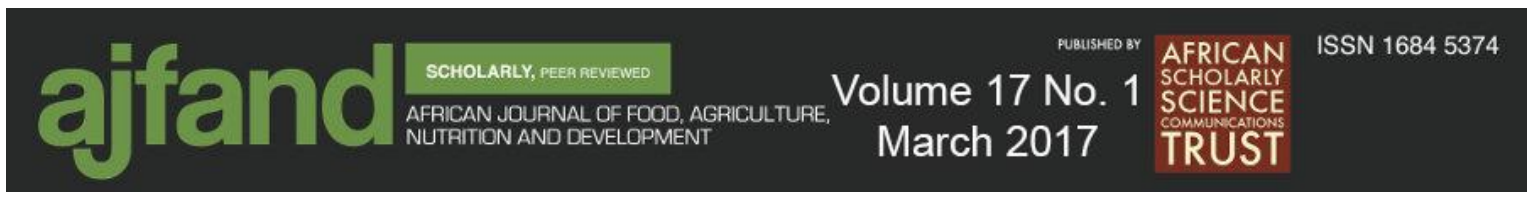

21. Mwesigye PK and TO Okurut A Survey of the Production and Consumption of Traditional Alcoholic Beverages in Uganda. Process Biochemistry. 1995;30(6):497501. doi: http://dx.doi.org/10.1016/0032-9592(94)00033-6.

22. Asiki G, Stockdale L, Kasamba I, Vudriko T, Tumwekwase G, Johnston T, Kaleebu P, Kamali A, Seeley $\mathbf{J}$ and $\mathbf{R}$ Newton A pilot study of antibodies against Varicella Zoster Virus (VZV) and human immunodeficiency virus (HIV) in relation to the risk of developing stroke, nested within a rural cohort in Uganda. Medicine \& International Health. 2015; 20(10):1306-10.

23. Nunn AJ, Kengeya-Kayondo JF, Malamba SS, Seeley JA and DW Mulder Risk factors for HIV-1 infection in adults in a rural Ugandan community: a population study. AIDS, 1994; 8(1): 81-6.

24. Asiki G, Murphy G, Nakiyingi-Miiro J, Seeley J, Nsubuga RN, Karabarinde A, Waswa L, Biraro S, Kasamba I, Pomilla C, Maher D, Young EH, Kamali A, Sandhu MS, on behalf of the GPC team. The General Population Cohort in rural south-western Uganda: a platform for communicable and non-communicable disease studies. Int J Epidemiol, 2013.

25. Taylor B, Bukenya D, van Asten P, Agol D, Pain A and J Seeley The impact of HIV on agricultural livelihoods in southern Uganda and the challenges of attribution. Tropical Medicine and International Health. 2011;16(3):324-33. doi:10.1111/j.13653156.2010.02703.x.

26. Abbas HK, Cartwright RD, Xie W and SW Thomas Aflatoxin and fumonisin contamination of corn (maize, Zea mays) hybrids in Arkansas. Crop Protection. 2006;25(1):1-9. doi: http://dx.doi.org/10.1016/j.cropro.2005.02.009.

27. Jolly P, Jiang Y, Ellis W, Awuah R, Nnedu O, Phillips T, Wang J, Afriyie-Gyawu E, Tang L, Person, Williams SJ and C Jolly Determinants of aflatoxin levels in Ghanaians: Sociodemographic factors, knowledge of aflatoxin and food handling and consumption practices. International Journal of Hygiene and Environmental Health. 2006;209(4):345-58. doi: http://dx.doi.org/10.1016/j.ijheh.2006.02.002.

28. Ngindu A, Kenya PR, Ocheng DM, Omondi TN, Ngare W and D Gatei Outbreak of acute hepatitis caused by aflatoxin poisining in Kenya The Lancet. 1982;319(8285):1346-8. doi: http://dx.doi.org/10.1016/S0140-6736(82)92411-4.

29. Oruc HH, Cengiz $\mathbf{M}$ and $\mathbf{O}$ Kalkanli Comparison of aflatoxin and fumonisin levels in maize grown in Turkey and imported from the USA. Animal Feed Science and Technology. 2006;128(3-4):337-41. doi:

http://dx.doi.org/10.1016/j.anifeedsci.2006.02.008.

30. Widstrom NW The Aflatoxin Problem with Corn Grain. In: Donald LS (ed).. Advances in Agronomy. Academic Press; 1996. p. 219-80. 


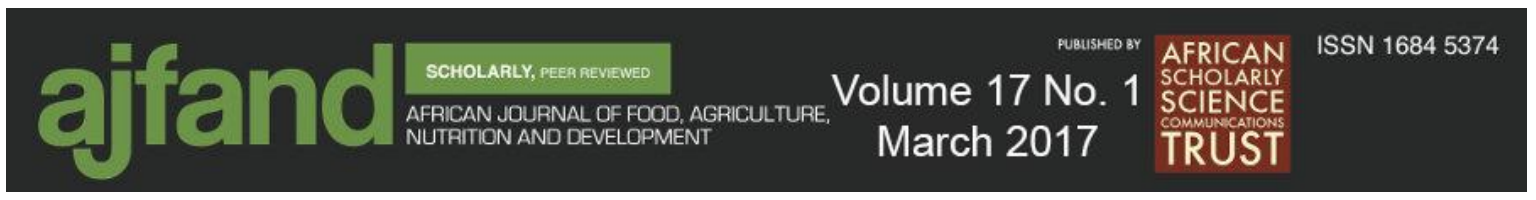

31. Garrido CE, Hernández Pezzani C and A Pacin Mycotoxins occurrence in Argentina's maize (Zea mays L.), from 1999 to 2010. Food Control. 2012;25(2):6605. doi: http://dx.doi.org/10.1016/j.foodcont.2011.11.043.

32. Gnonlonfin GJB, Adjovi CSY, Katerere DR, Shephard GS, Sanni A and L

Brimer Mycoflora and absence of aflatoxin contamination of commercialized cassava chips in Benin, West Africa. Food Control. 2012;23(2):333-7. doi:

http://dx.doi.org/10.1016/j.foodcont.2011.07.026.

33. Jager AV,Tedesco MP, Souto PCMC and CAF Oliveira Assessment of aflatoxin intake in São Paulo, Brazil. Food Control. 2013;33(1):87-92. doi: http://dx.doi.org/10.1016/j.foodcont.2013.02.016.

34. Mutegi CK, Ngugi HK, Hendriks SL and RB Jones Prevalence and factors associated with aflatoxin contamination of peanuts from Western Kenya. International Journal of Food Microbiology. 2009;130(1):27-34. doi: http://dx.doi.org/10.1016/j.ijfoodmicro.2008.12.030.

35. Gnonlonfin GJB, Adjovi YC, Tokpo AF, Agbekponou ED, Ameyapoh Y and C de Souza Mycobiota and identification of aflatoxin gene cluster in marketed spices in West Africa. Food Control. 2013;34(1):115-20. doi:

http://dx.doi.org/10.1016/j.foodcont.2013.04.021.

36. Ezekiel CN, Sulyok M, Babalola DA, Warth B, Ezekiel VC and R Krska Incidence and consumer awareness of toxigenic Aspergillus section Flavi and aflatoxin B1 in peanut cake from Nigeria. Food Control. 2013;30(2):596-601. doi: http://dx.doi.org/10.1016/j.foodcont.2012.07.048.

37. Hell K, Gnonlonfin BGJ, Kodjogbe G, Lamboni Y and IK Abdourhamane Mycoflora and occurrence of aflatoxin in dried vegetables in Benin, Mali and Togo, West Africa. International Journal of Food Microbiology. 2009;135(2):99-104. doi: http://dx.doi.org/10.1016/j.ijfoodmicro.2009.07.039. 